a supply of phisohex; to Messrs. Hough-Hoseason for supplies of ster-zac liquid soap and tegolan emulsion; to Mr. J. W. Hadgraft, of the Royal Free Hospital, for a supply of compound hexachlorophane cream; to British Drug Houses for a supply of dichlorophene; to Pearson's Antiseptic Company Limited for supplies of hycolin cream and liquid soap; to Willows Francis Limited for supplies of steriloderm and steriloderm forte ; to Berk Pharmaceuticals Limited for a supply of betadine surgical scrub; and to Mrs. M. Kilner for secretarial assistance.

\section{REFERENCES}

Barber, M., and Kuper, S. W. A. (1951). J. Path. Bact., 63, 65. Beilby, J. O. W., and Thompson, R. E. M. (1961). Brit. J. Surg., 48, 598. (1950). J. invest. Derm., 15, 305 .

Fisher, R. A (1942) In The Design of Experiments, 3rd ed. p. 68. Oliver and Boyd, Edinburgh.
Frisby, B. R. (1959). Lancet, 2, 57.

Hare, R., and Ridley, M. (1958), Brit. med. J., 1, 69 Hufnagei, C. A., Walter, C. W., and Howard, R. W. (1948). Surgery, 23, 753.

Joress, S. M. (1962). Ann. Surg., 155, 296.

Larkin, I. M., Bridson, E. Y., Grieve, W. S. M., and Gibson, J.W. (1961). J. clin. Path., 14, 80.

Lowbury, E. J. L., and Lilly, H. A. (1960). Brit, med. J., 1, 1445 .

and Bull, J. P. (1960). Ibid., 2, 1039

Murray, J., and Calman, R. M. (1955). Ibid., 1, 81

Price, P. B. (1938). J. infect. Dis., 63, 301.

- (1951). Ann. Surg., 134, 476

(1957). In Antiseptics, Disinfectants, Fungicides, and Chemical and Physical Sterilization, edited by G. F. Reddish, 2nd ed. Kimpton, London.

Schmitz, I. A., and Harris, S. W. (1958). Mfg Chem., 29, 51.

Smylie, H. G., Webster, C. U., and Bruce, M. L. (1959). Brit. med. J., 2, 606.

Walter, C. W.'(1948). The Aseptic Treatment of Wounds, p. 185. MacMillan, New York

Zintel, H. A. (1956). Surg. Clin. N. Amer., 36, 257.

\title{
NITROGEN MUSTARD THERAPY WITH AORTIC OCCLUSION IN NASOPHARYNGEAL CARCINOMA
}

\author{
PETER CLIFFORD, M.Ch., D.L.O. \\ Consultant Surgeon \\ J. L. BEECHER, M.B., B.S. \\ Surgical Registrar \\ J. R. HARRIES, M.D., M.R.C.P. \\ Consultant Physician
}

BY

\author{
H. G. OETTGEN, M.D. \\ Honorary Consultant Chemotherapist \\ F. P. BROWN, M.B., B.S. \\ Anaesthetist \\ W. E. LAWES, F.F.A. R.C.S. \\ Consultant Anaesthetist
}

From the Department of Head and Neck Surgery and the Respiratory Unit, King George VI Hospital, Nairobi, and the Division of Clinical Chemotherapy, Sloan Kettering Institute for Cancer Research, New York

The incidence of malignant disease of the head and neck area, relative to other parts of the body, is higher in hospital patients in Kenya than in Europe or America (Clifford, 1961). In the five-year period 1956-60, patients with a primary neoplastic growth in this area constituted one-third of all those with malignant disease admitted to the King George VI Hospital, Nairobi. Undifferentiated growths of the post-nasal space formed the largest group. The patients admitted were classified as follows:

$$
\begin{aligned}
& \text { Total number suffering from malignant } \\
& \text { disease (1956-60) } \\
& \begin{array}{c}
\text { malignancy } \\
\text { Patients with a post-nasal space malig- }
\end{array}
\end{aligned}
$$

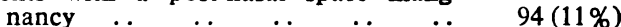

Digby, Fook, and Che (1941) drew attention to the prevalence of carcinoma of the nasopharynx in Hong Kong, and the clinical picture as described by them is similar to that seen in Kenya. Histologically the tumours are very poorly differentiated and the commonest presenting symptoms are those associated with enlarged secondary neck glands. The disease affects patients of both sexes from the ages of 15 to 55 years, mean about 30 years.

Surgery has no place in the treatment of malignant disease of the post-nasal space (Lederman, 1961), and, as radiotherapy is not available in Kenya, nitrogen mustard (HN2) has been used since 1956 in this department. Initially the recommended pharmacopoeial dose $(0.1 \mathrm{mg}$. $/ \mathrm{kg}$. body weight, daily for five days) was given, the aim being palliation. Experience suggested that tumour response was proportional to the dose administered (Clifford, Clift, and Duff, 1961), and consequently attention was directed to the development of methods designed to allow larger doses of the drug to be given with safety to the patient. By using auto- logous marrow infusion to counteract bone-marrow toxicity, $2 \mathrm{mg}$. of $\mathrm{HN} 2 / \mathrm{kg}$. body weight was given without fatality (Clifford et al., 1961); although the immediate palliative results were satisfactory, the tumour and symptoms recurred.

Miller and Lawrence (1961) developed a method of protecting the pelvic bone-marrow by temporarily occluding the abdominal aorta, but noted that a dose of $1.2 \mathrm{mg}$. of $\mathrm{HN} 2 / \mathrm{kg}$. produced auditory-nerve damage. To avoid this and other cerebral complications, it was decided to fractionate the dose of $\mathrm{HN} 2$, at the same time protecting the pelvic bone-marrow by aortic occlusion. Duff, Dennis, Clift, Clifford, and Oettgen (1961) have described this technique and reported the immediate effects of administering $1.5-3 \mathrm{mg}$. of $\mathrm{HN} 2 /$ $\mathrm{kg}$. body weight by this method to 10 patients with anaplastic carcinoma of the post-nasal space or midthird of the oesophagus. The present paper describes the developments and modifications in technique introduced as the result of further experience with this form of therapy, and the method is evaluated with reference to the complications and therapeutic effects noted in 18 patients with anaplastic carcinoma of the post-nasal space.

\section{Assessment and Investigations}

Prior to treatment the following investigations were carried out in each case.

1. Nature and Extent of Disease.-The diagnosis in all cases was confirmed by a positive biopsy from the post-nasal space. Negative clinical examination of this area may be misleading and patients suspected of having a growth were examined under general anaesthesia. The post-nasal space was carefully palpated by a finger 
inserted behind the soft palate; biopsies were taken with a Luc's forceps introduced through the nose and guided in the post-nasal space by the examining finger. In many instances a primary tumour was not palpated, but linear strip biopsies of the mucous membrane of the post-nasal space were positive on histological examination. $X$-ray films of the chest, base of the skull, and nasal sinuses were taken in all cases, and further radiological studies were made when necessary to assess the extent of the disease. Malignant metastases above the level of the transumbilical line were not regarded as a contraindication to this form of therapy. In female patients pregnancy was excluded.

2. As diaphragmatic movement is restricted during occlusion, prior clinical assessment of pulmonary reserve was made in all cases. Respiratory-function tests were performed if there were large intrathoracic secondary deposits or if the patient suffered from chronic obstructive emphysema.

3. The cardiovascular state was assessed by clinical examination, electrocardiography, and postero-anterior chest $x$-ray films.

4. Routine haemoglobin estimations and leucocyte and platelet counts were made before, during, and after treatment. In addition, sternal and iliac bone-marrow aspirations were examined at the same time.

5. Because large doses of $\mathrm{HN} 2$ produce cerebral toxicity, the auditory nerve being particularly sensitive, all patients had audiograms recorded prior to treatment. A complete neurological examination was undertaken before and after treatment in selected cases. Evidence of encephalopathy or senility was regarded as an absolute contraindication to this form of therapy.

6. Biochemical investigations included serum bilirubin, serum alkaline phosphatase, blood urea, and electrolyte estimations.

\section{Dosage}

Previously it was noted (Duff et al., 1961) that a total dose of $3 \mathrm{mg} . / \mathrm{kg}$. given as quarter-doses during two 20 -minute periods of occlusion within a week was apt to produce tinnitus, deafness, and mental confusion. Since then it has been found that this dosage may produce progressive cerebral degeneration ending in death, and this was particularly likely to occur in middle-aged or elderly patients. In this series it was decided to give $2.5 \mathrm{mg}$. of $\mathrm{HN} 2 / \mathrm{kg}$. as $0.8,0.8$, and $0.9 \mathrm{mg} . / \mathrm{kg}$. with three occlusions within a threeweeks period. The effective tumour dose was estimated to be slightly less than 5 $\mathrm{mg} . / \mathrm{kg}$. The longer interval between occlusions would allow the patient to recover from the effects of any gastrointestinal toxicity which might occur and provide an opportunity for reassessing the patient before the treatment was continued. HN2 is fixed in the tissues within 10 minutes of administration to normothermic patients (Ryan, Winblad, Krementz, and Creech, 1958). By occluding the abdominal aorta for 10 minutes the pelvic marrow is protected from the toxic effects of HN2 injected intravenously above the level of the occlusion.

\section{Method of Occlusion}

Anaesthetic Technique.-Before and after intubation particular care was paid to oxygenation. The tourniquet was applied when the patient was fully relaxed (with gallamine triethiodide). Unless additional studies were being undertaken during the occlusion, manual insufflation was used. It was noted that with manual intermittent positive pressure the pressure waves coinciding with the application of positive pressure were recorded in the femoral arteries, independent of the type of occlusion, but were not recorded when mechanical positive-pressure respiration was used with a Barnet ventilator; this difference is probably due to a natural tendency on the part of the anaesthetist to use too high a manual pressure on inspiration.

Occlusion.-A Kidde tourniquet is used with a specially designed rubber cuff, 8 in. $(20 \mathrm{~cm}$.) wide, which completely encircles the abdomen. The cuff is so placed that when inflated the lower abdominal aorta is occluded. A pressure of $150-200 \mathrm{~mm}$. $\mathrm{Hg}$ is produced in the

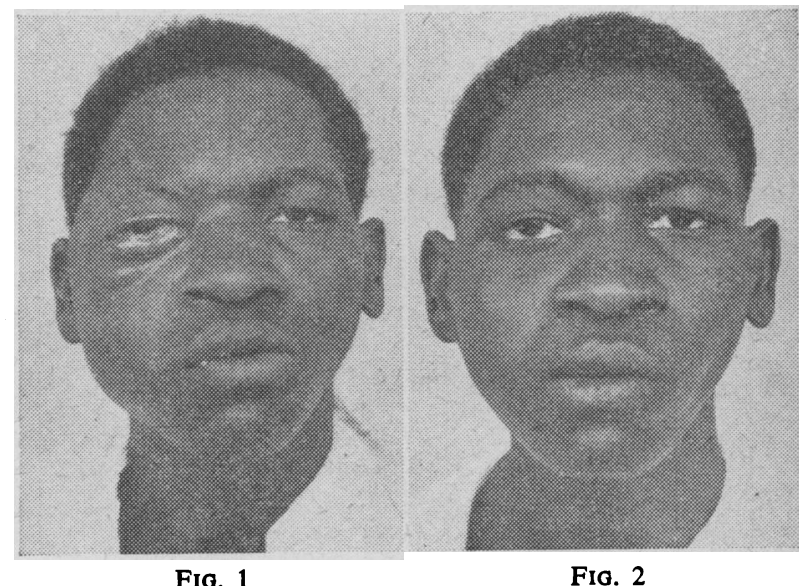

FIG. 1.-Case 1. A 16-year-old Kikuyu boy presenting with pain in right side of face, trismus, epistaxis, proptosis of right eye,
and paresis of the right II, III, IV, V, VI, VII, VIII, IX, and $X$ cranial nerves. Biopsies from the post-nasal space and right $X$ cranial nerves. Biopsies from the post-nasal space and right
cervical gland mass showed an anaplastic carcinoma. FIo. 2.cervical gland mass showed an anaplastic carcinoma. F
Case 1. Appearance six weeks after treatment.

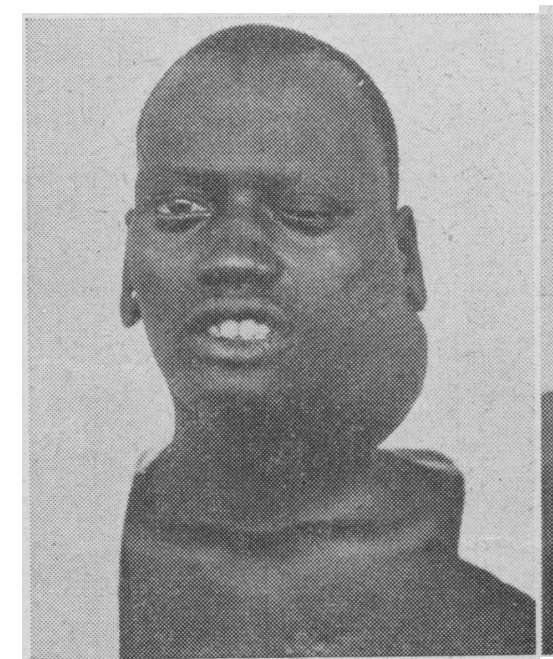

Fig. 3

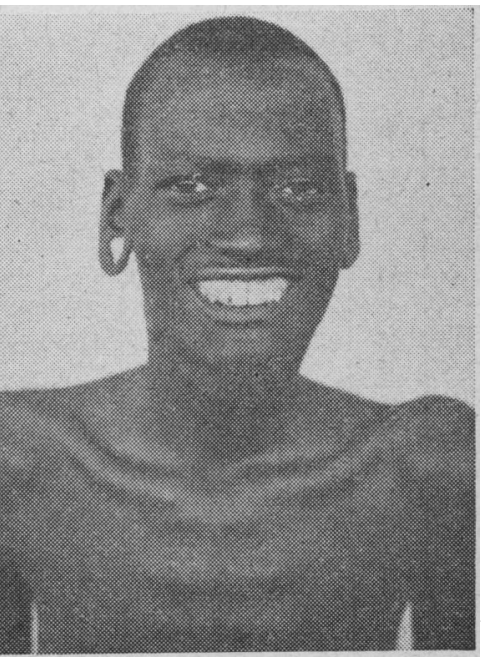

FIG. 4

FIG. 3.-Case 14. A 25-year-old Nandi man presenting with pain in left side of

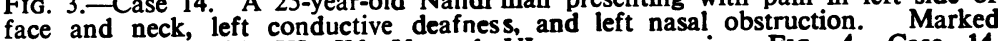
ptosis left eye with III, IV, $V$, and VI nerve paresis. FIo. 4.-Case 14. ptosis left eye with Appearance four weeks after treatment. 
tourniquet from a Medicair cylinder (compressed dichloro-difluoro-methane). The HN2 solution, prepared immediately before injection in a concentration of $1 \mathrm{mg} . / \mathrm{ml}$. of $0.9 \%$ saline, is rapidly injected intravenously through a Gordh needle, which is subsequently flushed through with saline. The occlusion is maintained for 10 minutes after the injection is complete, to allow for the elimination of all active drug from the circulating blood (Ryan et al., 1958).

\section{Results}

Figs. 1 to 4 show two typical cases of the disease in Kenya Africans, before and after treatment.
The presenting clinical picture and the treatment and response in 18 patients with anaplastic carcinoma of the post-nasal space are outlined in Table I. It will be noted that one patient (Case 3 ) died from a mechanical effect of occlusion-that is, cardiac arrest subsequent to a ruptured diaphragm. Three patients (Cases 5, 6, and 8) died from HN2 toxicity. Case 1 had had previous treatment with a combination of actinomycin D, chlorambucil, and methotrexate, with no effect. Cases 2, 4, and 9 had intra-arterial regional infusions of 5-fluorodeoxyuridine without any marked anti-tumour response. Cases 2, 6, and 16, given initial courses of 1.5-1.6 mg. $\mathrm{HN} 2 / \mathrm{kg}$, had no or only partial tumour regression,

TABle I.-Presenting Clinical Picture, Dates and Doses of Treatment, and Response in 18 Patients with Anaplastic Carcinoma of Post-nasal Space

\begin{tabular}{|c|c|c|c|c|c|c|c|c|c|}
\hline \multirow{2}{*}{$\begin{array}{l}\text { Case } \\
\text { No. }\end{array}$} & \multirow{2}{*}{$\begin{array}{l}\text { Sex } \\
\text { and } \\
\text { Age }\end{array}$} & \multirow{2}{*}{$\begin{array}{l}\text { Presenting } \\
\text { Symptoms }\end{array}$} & \multicolumn{2}{|c|}{ Clinical Extent of Disease } & \multicolumn{2}{|c|}{ Treatment } & \multicolumn{2}{|c|}{ Response } & \multirow[b]{2}{*}{ Remarks } \\
\hline & & & $\begin{array}{l}\text { Tumour } \\
\text { Deposits }\end{array}$ & $\begin{array}{l}\text { Other } \\
\text { Signs }\end{array}$ & Date & $\underset{\text { (mg./kg.) }}{\text { Dose }}$ & $\begin{array}{l}\text { Tumour } \\
\text { Regression }\end{array}$ & $\begin{array}{l}\text { Biopsy with } \\
\text { Date }\end{array}$ & \\
\hline 1 & $\begin{array}{l}M \\
16\end{array}$ & $\begin{array}{l}\text { Pain and trismus } R \text {. } \\
\text { temp.-mand. joint. } \\
\text { R. tinnitus and } \\
\text { headache. Diminu- } \\
\text { tion of vision. } R \text {. } \\
\text { epistaxis }\end{array}$ & $\begin{array}{l}\text { P.N.S. R. orbit. } \\
\text { R. cervical glands }\end{array}$ & $\begin{array}{l}\text { Paresis R. II, III, } \\
\text { IV, V, VI, VII, } \\
\text { VII, IX, X } \\
\text { cranial nerves }\end{array}$ & $7,16,26 / 6 / 61$ & $2 \cdot 5(116)$ & $\begin{array}{l}\text { Total. III, IV, } \\
\text { VI nerve } \\
\text { lesions } \\
\text { cured, others } \\
\text { improved }\end{array}$ & $\underset{24 / 7 / 61}{\text { P.N.S. nes. }}$ & $\begin{array}{l}\text { Had actinomycin } \\
\text { D, chlorambucil, } \\
\text { and methotrexate, } \\
\text { Nov, 1960. Re- } \\
\text { admitted with } \\
\text { recurrence, } 2 / 3 / 62\end{array}$ \\
\hline 2 & $\begin{array}{r}F \\
16\end{array}$ & $\begin{array}{l}\text { Trismus. L. neck } \\
\text { pain }\end{array}$ & $\begin{array}{l}\text { P.N.S. Small } \\
\text { node L. neck }\end{array}$ & $\underset{\text { cranial nerve }}{\text { Paresis }}$ & $\begin{array}{l}16,27 / 6 / 61 \\
21,28 / 7 \text { and } \\
9,8 / 61\end{array}$ & $\begin{array}{l}1 \cdot 6(52) \\
2 \cdot 5(84)\end{array}$ & $\begin{array}{l}\text { (1) Partial } \\
\text { (2) Total }\end{array}$ & $\underset{25 / 8 / 61}{\text { P.N.S. nneg. }}$ & $\begin{array}{l}\text { Had F.U.D.R. } \\
\text { intra-arterially } \\
\text { March and April } \\
\text { May, 1961. Died, } \\
\text { at home, Feb. } \\
1962\end{array}$ \\
\hline 3 & $\underset{50-60}{F}$ & $\begin{array}{l}\text { Painful swelling } L \text {. } \\
\text { side of neck }\end{array}$ & $\begin{array}{l}\text { Ulcerating cancer. } \\
\text { P.N.S. Large L. } \\
\text { neck glands }\end{array}$ & - & $8,15 / 3 / 61$ & $1.6(67)$ & - & - & $\begin{array}{l}\text { Died after cardiac } \\
\text { arrest at 2nd oc- } \\
\text { clusion (rupture of } \\
\text { diaphragm) }\end{array}$ \\
\hline 4 & $\underset{45-60}{M}$ & $\begin{array}{l}\text { Painful swelling of } \\
\text { neck }\end{array}$ & $\begin{array}{l}\text { Large P.N.S. } \\
\text { tumour. Large L. } \\
\text { neck and small R. } \\
\text { neck glands }\end{array}$ & - & $7,16,26 / 6,61$ & $2 \cdot 5(140)$ & Total & $\begin{array}{l}\text { P.N.S. and } \\
\text { glands neg. } \\
19 / 7 / 61\end{array}$ & $\begin{array}{l}\text { diaphragm) } \\
\text { Had F.U.D.R. } \\
\text { intra-arterially } \\
\text { March and April, } \\
\text { 1961. Died at }\end{array}$ \\
\hline 5 & $\begin{array}{l}\mathbf{M} \\
35\end{array}$ & $\begin{array}{l}\text { Swelling R. neck. } \\
\text { Headache, block- } \\
\text { age of nose }\end{array}$ & $\begin{array}{l}\text { P.N.S. Bilateral } \\
\text { moderate neck } \\
\text { glands }\end{array}$ & - & $\begin{array}{c}19,26 / 7 \\
4 / 8 / 61\end{array}$ & $2 \cdot 5(168)$ & Partial & - & $\begin{array}{l}\text { home, Nov., } 1961 \\
\text { Died of toxicity, } \\
9 / 9 / 61\end{array}$ \\
\hline 6 & $\begin{array}{r}F \\
20\end{array}$ & $\begin{array}{l}\text { Painful swelling L. } \\
\text { jaw. Trismus, } \\
\text { anorexia }\end{array}$ & $\begin{array}{l}\text { P.N.S. palate. } \\
\text { Bilateral neck } \\
\text { glands }\end{array}$ & - & $\begin{array}{l}19,26 / 4 / 61 \\
24,31 / 5 \text { and } \\
7 / 6 / 61\end{array}$ & $\begin{array}{l}1 \cdot 5(70) \\
2 \cdot 5(105)\end{array}$ & Nil & 二 & Died of toxicity, $_{15 / 6 / 61}$ \\
\hline 7 & $\underset{25}{F}$ & $\begin{array}{l}\text { Swelling R. neck. } \\
\text { Periodic fever. } \\
\text { Weight loss }\end{array}$ & $\begin{array}{l}\text { P.N.S. Moderate } \\
\text { R. neck and small } \\
\text { L. neck glands }\end{array}$ & - & $\begin{array}{l}11,18,29 / 5 \\
31,7 \text { and } \\
4,9 ; 8,61\end{array}$ & $\begin{array}{l}2 \cdot 5(103) \\
2 \cdot 5(110)\end{array}$ & $\begin{array}{l}\text { 1. Partial } \\
\text { 2. Total }\end{array}$ & $\begin{array}{l}\text { 1. P.N.S. neg. } \\
\text { neck pos. } \\
29 / 5 / 61\end{array}$ & $\begin{array}{l}\text { Discharged without } \\
\text { proof biopsy. } \\
\text { Untraceable }\end{array}$ \\
\hline 8 & $\underset{40}{F}$ & $\begin{array}{l}\text { Swelling of neck. } \\
\text { Dysphagia. } \\
\text { Tinnitus }\end{array}$ & $\begin{array}{l}\text { P.N.S. Small R } \\
\text { neck glands }\end{array}$ & - & $\begin{array}{c}17,28 / 7 \\
1 / 8 / 61\end{array}$ & $2 \cdot 5(109)$ & $\begin{array}{l}\text { Total (at } \\
\text { necropsy) }\end{array}$ & 2. $=$ & $\begin{array}{l}\text { Died of toxicity, } \\
108 / 61\end{array}$ \\
\hline 9 & ${ }_{25}^{M}$ & $\begin{array}{l}\text { Pain } R \text {. face, block- } \\
\text { age } R \text {. nostril, } \\
\text { deafness } R \text {. ear }\end{array}$ & P.N.S., palate & $\begin{array}{l}\text { Paresis R. III, } \\
\text { IV, VI cranial } \\
\text { nerves. R. } \\
\text { deafness }\end{array}$ & $1,8,15 / 2 / 62$ & $2 \cdot 5(117)$ & $\begin{array}{l}\text { Total. Deaf- } \\
\text { ness cured. } \\
\text { III, IV, vi } \\
\text { nerve lesions }\end{array}$ & $\begin{array}{l}\text { P.N.S. neg. } \\
7 / 3 / 62\end{array}$ & $\begin{array}{l}\text { Had F.U.D.R. } \\
\text { intra-arterially } \\
\text { Aug.-Sept., } 1961 . \\
\text { Readmitted with }\end{array}$ \\
\hline 10 & $\begin{array}{l}M \\
40\end{array}$ & $\begin{array}{l}\text { Swelling } R \text {, neck, } \\
\text { vomiting, head- } \\
\text { ache, pain. Loss } \\
\text { of weight }\end{array}$ & $\begin{array}{l}\text { P.N.S., R. neck } \\
\text { glands }\end{array}$ & - & $\begin{array}{c}25,29 / 8 \\
6 / 9 / 61\end{array}$ & $2 \cdot 5(125)$ & $\begin{array}{l}\text { improved } \\
\text { Total }\end{array}$ & $\begin{array}{l}\text { P.N.S. and neck } \\
\text { neg. } 3 / 10 \text { '61. } \\
\text { P.N.S. neg. } \\
10^{\prime} 2,8 / 6 \text {, and }\end{array}$ & $\begin{array}{l}\text { recurrence 14/1/62 } \\
\text { Neck glands } \\
\text { showed tubercu- } \\
\text { lous adenitis as } \\
\text { well as carcinoma }\end{array}$ \\
\hline 11 & $\begin{array}{r}F \\
18\end{array}$ & $\begin{array}{l}\text { Swelling of neck. } \\
\text { Epistaxis }\end{array}$ & $\begin{array}{l}\text { P.N.S. Moderate } \\
\text { bilateral neck } \\
\text { glands }\end{array}$ & - & $8,18,29 / 9 / 61$ & $2 \cdot 5(107)$ & ," & P.N.S. neg. & $\begin{array}{l}\text { Readmitted with } \\
\text { recurrence, } 16 / 2 / 62\end{array}$ \\
\hline 12 & $\begin{array}{r}F \\
40\end{array}$ & $\begin{array}{l}\text { Swelling of neck. } \\
\text { Headache }\end{array}$ & $\begin{array}{l}\text { P.N.S. Moderate } \\
\text { bilateral neck } \\
\text { glands }\end{array}$ & - & $\begin{array}{l}8,22 / 9 \text { and } \\
2 / 10: 61\end{array}$ & $2 \cdot 5(87 \cdot 5)$ & " & $\begin{array}{l}\text { P.N.S. and neck } \\
\text { neg. } 3 / 11 / 61\end{array}$ & $\begin{array}{l}\text { Died at home, } \\
\text { Feb./March, } 1962\end{array}$ \\
\hline 13 & $\begin{array}{l}\text { M } \\
50\end{array}$ & $\begin{array}{l}\text { Hoarseness. Swollen } \\
\text { neck glands }\end{array}$ & $\begin{array}{l}\text { P.N.S. Moderate } \\
\text { bilateral neck } \\
\text { glands }\end{array}$ & $\begin{array}{l}\text { Paresis R.X., XI, } \\
\text { XII cranial } \\
\text { nerve. R. } \\
\text { Horner's } \\
\text { syndrome }\end{array}$ & $\begin{array}{l}2,6,11 / 10 / 61 \\
29 / 111 \text { and } \\
4 / 12 / 61\end{array}$ & $\begin{array}{l}2.5(124) \\
1.6(80)\end{array}$ & $\begin{array}{l}\text { 1. Total (no } \\
\text { change in } \\
\text { nerve signs) }\end{array}$ & $\begin{array}{l}\text { 1. P.N.S. Degen- } \\
\text { erate tumour } \\
\text { tissue. } \\
\text { 2. P.N.S. neg. } \\
5: 1 / 62\end{array}$ & $\begin{array}{l}\text { Second course } \\
\text { abandoned for } \\
\text { pneumonia. } \\
\text { Readmitted with } \\
\text { recurrence, } 30 / 3^{\prime} 62\end{array}$ \\
\hline 14 & $\begin{array}{l}\mathrm{M} \\
25\end{array}$ & $\begin{array}{l}\text { Painful swelling L. } \\
\text { side of neck }\end{array}$ & $\begin{array}{l}\text { P.N.S. Large L. } \\
\text { neck glands }\end{array}$ & $\begin{array}{l}\text { Paresis L. III, } \\
\text { IV, V. VI } \\
\text { cranial nerves }\end{array}$ & $\begin{array}{l}13,20 \\
27 / 10 / 61\end{array}$ & $2 \cdot 5(208)$ & Total & $\begin{array}{l}\text { P.N.S. and neck } \\
\text { neg. } 24,11^{\prime} 61 \\
\text { and } 22 / 2 / 62\end{array}$ & $\begin{array}{l}\text { Readmitted with } \\
\text { recurrence, } \\
106^{\prime} 62\end{array}$ \\
\hline 15 & $\begin{array}{l}M \\
\mathbf{4 8}\end{array}$ & $\begin{array}{l}\text { Blurred vision R. } \\
\text { eye. Blocked nose } \\
\text { and epistaxis. } \\
\text { Swelling L. neck }\end{array}$ & $\begin{array}{l}\text { Very large P.N.S. } \\
\text { tumour. Moder- } \\
\text { ate bilateral neck } \\
\text { glands }\end{array}$ & $\begin{array}{l}\text { Paresis R. IIT, } \\
\text { IV, VT cranial } \\
\text { nerves. L. con- } \\
\text { ductive deaf- } \\
\text { ness. R. partial } \\
\text { optic atrophy }\end{array}$ & 18,25 & $2 \cdot 5(138)$ & $\begin{array}{l}\text { Total. } \\
\text { Deafness } \\
\text { improved }\end{array}$ & $\begin{array}{c}\text { P.N.S. and neck } \\
\text { neg. } 24 / 11 / 61\end{array}$ & $\begin{array}{l}\text { Recurrence known, } \\
\text { May 1962. } \\
\text { Patient dying at } \\
\text { home }\end{array}$ \\
\hline 16 & $\underset{50}{F}$ & $\begin{array}{l}\text { Painful swelling } L \text {. } \\
\text { neck }\end{array}$ & $\begin{array}{l}\text { P.N.S. palate. } \\
\text { Large L. neck } \\
\text { glands. Trismus }\end{array}$ & Deaf L. ear & $\begin{array}{l}9,17,24 ! 1 / 62 \\
28: 2 \text { and } 7, \\
14 / 3 / 62\end{array}$ & $\begin{array}{l}1.6(50) \\
1.6(52 \cdot 5)\end{array}$ & $\begin{array}{l}\text { 1. Partial } \\
\text { 2. Total }\end{array}$ & $\begin{array}{l}\text { P.N.S. and neck } \\
\text { neg. } 1 / 4 / 62\end{array}$ & $\begin{array}{l}\text { Reduced dosage } \\
\text { because of pre- } \\
\text { existing marrow } \\
\text { hypoplasia. } \\
\text { Untraced }\end{array}$ \\
\hline 17 & $\begin{array}{l}\mathbf{M} \\
\mathbf{3 2}\end{array}$ & $\begin{array}{l}\text { Dyspnoea and dys- } \\
\text { phagia. sore throat, } \\
\text { swelling of neck. } \\
\text { Headache }\end{array}$ & $\begin{array}{l}\text { Large tumour } \\
\text { whole of pharynx. } \\
\text { Bilateral neck } \\
\text { glands. Trismus }\end{array}$ & $\begin{array}{l}\text { Paresis L. V. VTT } \\
\text { cranial nerves. } \\
\text { Some bilateral } \\
\text { deafness }\end{array}$ & $2,9,16 / 2 / 62$ & $2 \cdot 5(125)$ & $\begin{array}{l}\text { Total } \\
\text { (audiogram } \\
\text { unchanged) }\end{array}$ & $\begin{array}{l}\text { P.N.S. and neck } \\
\text { neg. } 7 / 3 / 62\end{array}$ & $\begin{array}{l}\text { Recurrence, } \\
\text { April, } 1962\end{array}$ \\
\hline 18 & $\begin{array}{l}\mathbf{M} \\
\mathbf{3 0}\end{array}$ & $\begin{array}{l}\text { Blockage nose, } \\
\text { swelling L. man- } \\
\text { dible, trismus, pain } \\
\text { L. ear. Ptyalism }\end{array}$ & $\begin{array}{l}\text { Large tumour } \\
\text { P.N.S., palate, } \\
\text { and oropharynx. } \\
\text { L. mandible and } \\
\text { L. neck glands }\end{array}$ & $\begin{array}{l}\text { Paresis L. V. VI, } \\
\text { VIII, X, XI, } \\
\text { XII cranial } \\
\text { nerves }\end{array}$ & $2,9,21 / 2 ! 62$ & $2 \cdot 5(96)$ & $\begin{array}{l}\text { Total (nerve } \\
\text { signs } \\
\text { unchanged) }\end{array}$ & $\begin{array}{l}\text { P.N.S. and } \\
\text { neg. } 9 / 3 / 62\end{array}$ & Untraced \\
\hline
\end{tabular}


whereas Cases $1,2,4,8,9,10,11,12,13,14,15,16$, and 18 , given $2.5 \mathrm{mg} . / \mathrm{kg}$., had total tumour regression. These clinical findings were in all cases confirmed by histological examination of repeat biopsy specimens. Thirteen were relieved of all signs and symptoms resulting from tumour bulk. Nasal obstruction, conductive deafness, pain, or headache due to cervical plexus pressure cleared, but the neurological defects noted in Cases $1,2,9,13,15,16$, and 18 showed a less constant response.

Of the 13 patients discharged clinically and histologically free of disease, three (Cases 1, 10, and 14) remained so for four months ; only one of these (Case 10) was still free of disease 12 months after treatment. The disease is known to have recurred in Cases 1, 9, 11, $13,14,15$, and 17. Seven other patients died : four (Cases $3,5,6$, and 8 ) while under treatment, and three (Cases 2,4 , and 12) at home from recurrence of the disease. Three patients (Cases 7, 16, and 18) are untraced.

These results may be summarized as follows:

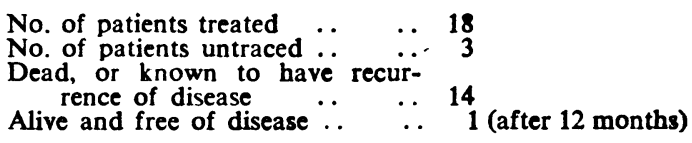

\section{Toxicity}

The symptoms of $\mathrm{HN} 2$ toxicity encountered are shown in Table II. Within the first 24 hours after the termination of the occlusion a profound fall in bloodpressure has been noted in some patients, and this may be evident at any time within 48 hours after occlusion. The causative factors have not yet been established, but may be due to the parasympatheticomimetic effects of the drug. Nausea, vomiting, and diarrhoea may occur within the week after occlusion, and detailed electrolyte studies and electrolyte replacement are necessary to avoid serious deficiencies due to loss through the alimentary tract. It is not yet certain whether these complications are due to cerebral or gastro-intestinal toxicity.

Of the four patients who died while under treatment, the cause of death in three (Cases 5, 6, and 8) was cerebral toxicity, though gastro-intestinal effects were contributory in Case 8 . In these three cases neurological disturbances became evident three to four days after occlusion. Drowsiness, confusion, and disorientation progressing to delirium and coma formed the pattern; twitching and fits were rare. Tinnitus and deafness were common in all patients after occlusions, but usually cleared within two weeks, though a nonincapacitating perceptive deafness persisted in one patient. Gastro-intestinal toxicity manifest by vomiting (15 times in 23 courses) and diarrhoea ( 8 times) generally occurred within the first 48 hours, and persisted for one to four days in relation to each occlusion. Haematological depression was usually maximal about 14 days after the last occlusion. The lowest counts noted are shown in Table II. Serial sternal and iliac marrow aspirations confirmed the effectiveness of the occlusions. Within five days of the occlusion the sternal marrow showed signs of toxic depression; this was most marked 14 to 16 days after the occlusion, at which time the iliac marrow was extremely hyperactive. These studies will be published in detail (Oettgen, Gillmore, and Wallace).

\section{Discussion}

Malignant disease in the African is usually far advanced when the patient first presents for treatment. In this series of 18 patients with anaplastic carcinoma of the post-nasal space the cervical glands were involved in all cases on first examination. Lederman (1961), referring to Jacod, has attempted to correlate the extent of the disease from the presenting neurological defects. Reference to the cranial nerves involved in eight of these patients, as shown in Table I, illustrates how widely the disease may disseminate. It is interesting to note that the seventh or eighth nerves were involved in three patients, which Lederman regards as rare. The failure of treatment to restore nerve function suggests that the paralysis was due to destruction of the nerve by tumour and not to compression. Lederman has stated that "advanced cancer is incurable by any method of treatment, the undifferentiated cancers are the most deadly primary tumours of the nasopharynx and tho

TABLE II.-Toxicity Encountered

\begin{tabular}{|c|c|c|c|c|c|c|c|c|c|c|}
\hline \multirow{2}{*}{$\begin{array}{l}\text { Case } \\
\text { No. }\end{array}$} & \multicolumn{5}{|c|}{ C.N.S. Signs } & \multirow{2}{*}{ Alopecia } & \multicolumn{2}{|c|}{$\begin{array}{c}\text { Gastro-intestinal } \\
\text { Signs }\end{array}$} & \multicolumn{2}{|c|}{$\begin{array}{c}\text { Haematology } \\
\text { (Lowest Count) }\end{array}$} \\
\hline & Dizziness & Headache & Drowsiness & $\begin{array}{l}\text { Conusion, } \\
\text { Coma }\end{array}$ & Deafness & & Vomiting & Diarrhoea & W.B.C. $/$ c.mm. & Platelets/c.mm. \\
\hline $\begin{array}{l}1 \\
2+\{ \\
3 * \\
4 \\
5^{*} \\
6+\{ \\
7+\{ \\
8 * \\
9 \\
11 \\
11 \\
13+\{ \\
14 \\
15 \\
16+\{ \\
17 \\
18\end{array}$ & + & $\begin{array}{l} \pm \\
+ \\
+\end{array}$ & + & $\begin{array}{l}++++ \\
+++ \\
++++ \\
++++\end{array}$ & + & +++ & $\begin{array}{c}+ \\
\\
++ \\
++ \\
++ \\
+ \\
+ \\
++ \\
++ \\
+ \\
+ \\
++ \\
++ \\
+ \\
+ \\
+ \\
+ \\
+\end{array}$ & $\begin{array}{c} \pm \\
++ \\
++ \\
++ \\
+\end{array}$ & $\begin{array}{r}200 \\
2,300 \\
2,200 \\
2, \overline{700} \\
2,000 \\
400 \\
-, 000 \\
1,600 \\
1,400 \\
2,000 \\
2,400 \\
2,500 \\
2,200 \\
2,200 \\
2,050 \\
1,450 \\
2,300 \\
2,600 \\
2,000 \\
2,900\end{array}$ & 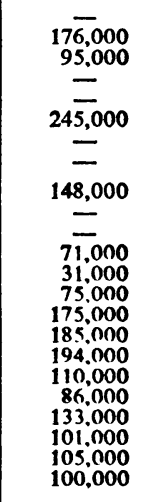 \\
\hline
\end{tabular}


results of radiotherapy are universally poor." In his series the average survival period for patients who succumbed to this disease was 16.8 months.

The primary objective of treatment was to relieve pain. Previous experience had suggested that the degree of tumour regression was proportional to the dosage of HN2 administered. With the method described, a body dose of $2.5 \mathrm{mg}$. $/ \mathrm{kg}$. produces an effective tumour dose slightly less than $5 \mathrm{mg}$. $/ \mathrm{kg}$. In the absence of radiotherapy the value of this form of treatment is shown by a complete clinical and histological regression of the tumour in 13 patients who presented with the disease in an advanced state. This dosage of $\mathrm{HN} 2$ is not curative ; only one patient (Case 10) was free of disease for longer than six months. By careful electrolyte replacement the hazards of gastro-intestinal toxicity can be contained, and by using the Kidde tourniquet leucopenia has not been a problem, but the factor which is limiting an increase in the dosage is cerebral toxicity. We now know that a dose of $3 \mathrm{mg}$. of $\mathrm{HN} 2 / \mathrm{kg}$. given by this method is not curative and will in most patients produce fatal cerebral toxicity (Clifford, 1962). If larger doses are to be administered the brain must be protected from the drug. The danger of treating cases with encephalopathy or senility has already been mentioned; some are completely unsuitable, but others will tolerate smaller doses given over longer intervals, with satisfactory palliative results. It has been noted that with this form of treatment the patient is liable to suffer a sudden and severe hypotensive episode at any time within 48 hours of the occlusion; this, if untreated, can be fatal.

The Kidde tourniquet used with a Baum cuff is simple and easily applied. The operator has complete control over the pressure, which is adjustable and is automatically recorded and maintained. The cuff exerts pressure uniformly to the entire abdominal circumference. With the sandbags and Esmarch's bandage technique (Duff et al., 1961), the pressure cannot be adjusted and may vary with the elasticity of the bandage and the strength of the operator. The entire abdominal circumference is not occluded and the effectiveness of the occlusion may diminish if the normal lumbar lordosis is reduced by pressure applied to the anterior abdominal wall against a hard table. The Kidde tourniquet reduces the risk of intestinal injury as the minimal pressure is applied. The effectiveness of occlusion has been proved by serial iliac and sternal marrow aspiration. Manual intermittent positivepressure respiration produced pressure waves recorded in the femoral arteries, independent of the type of occlusion used. These breaks in the occlusion were not recorded when mechanical intermittent positive-pressure was used, and serial iliac and sternal marrow aspirations suggest that the leakage is not clinically significant.

\section{Summary}

Anaplastic carcinoma of the post-nasal space is the commonest head and neck tumour in Kenya Africans.

Nitrogen mustard $2.5 \mathrm{mg}$. $/ \mathrm{kg}$. administered in three fractions $(0.8,0.8,0.9 \mathrm{mg}$.) within a three-weeks period, while protecting the pelvic marrow by aortic occlusion temporarily, produced complete clinical and histological remission of the disease in 13 out of 18 patients. One of these is alive and free of disease after 12 months, three have been lost to follow-up, and nine are known to have had a recurrence of the disease within four months of treatment. Four patients died under treatment; three of these from cerebral toxicity. Nitrogen mustard $3 \mathrm{mg} . / \mathrm{kg}$. administered by this method is not curative and will produce fatal cerebral toxicity in the majority of patients.

The Kidde tourniquet, using compressed dichlorodifluoromethane, easily and effectively occludes the abdominal aorta, and the symptoms of bone-marrow toxicity have not been a problem.

Femoral artery pressure recordings show that mechanical intermittent positive-pressure respiration is preferable during the period of occlusion.

A sudden and severe hypotensive episode may occur within 48 hours after occlusion and if untreated may be fatal.

Careful electrolyte estimations and replacement are important in gastro-intestinal toxicity.

We thank those members of the Medical Research Laboratory, Nairobi, who assisted us in this study; Dr. C. A. Linsell and Dr. W. de C. Baker for the histological reports; Mr. J. Gillmore for the haematological and marrow reports; and Mr. Pearson for the biochemical estimations. We are grateful to Dr. L. R. Whittaker for the radiological studies, and to the sisters and staff of the Head and Neck Department and the Respiratory Unit for their care in nursing these patients. A grant from the African Medical and Research Foundation helped to cover the cost of following up the patients in this series. We are grateful to Mrs. I. Kealey and Mrs. R. Martyn for their assistance with the preparation of the manuscript.

REFERENCES

Clifford, P. (1961). J. Laryng., 75. 707

(1962). Kenya Cancer Council, Head and Neck Section Reports, 1-26.

Clift, R. A., and Duff, J. K. (1961), Lancet, 1, 687

Digby, K. H., Fook, W. L., and Che, Y. T. (1941). Brit. J. Surg., 28, 517.

Duff, J., 28, H. F (1961). Brit., med. J., 2, 1523 .

Lederman, M. (1961). Cancer of the Nasopharynx. Thomas, Springfield, Illinois, U.S.A.

Miller, D. G., and Lawrence, W. (1961). Proc. Amer. Ass. Cancer Res., 3. 251

Ryan, R. F., Winblad, J. N., Krementz, E. T., and Creech, $\mathbf{O}$ (1958). "Bull. Tulane med. Fac., 17, 133.

"What, then, is the actual magnitude of the problem of mental illness in the world to-day ? . . . Exact assessment of the amount of mental illness is difficult, partly owing to the lack of accurate statistical information in many countries, and partly because many minor cases of mental ill-health are not recognized. It can be said, however, that in countries which are still very under-developed, and where the people still live the traditional life which their forebears lived, the problem is small. The incidence of psychiatric disturbances in tribal Africans has been said to be about a tenth of that usually found in Western Earope and North America. With the development of a country, however, especially if this has been too rapidly and inharmoniously planned, and especially with urbanization, industrialization, and the unregulated introduction of an alien culture when hitherto unsophisticated people become the victims of what has been described as 'cross-cultural shock,' the problem seems to increase rapidly. This problem is illustrated by the statement which you will perhaps remember was made by the distinguished delegate for Thailand at last year's Assembly when he called attention to the fact that, in his country, the diagnosed cases of frank psychoses and psychoneuroses had increased from one to an estimated two per 1,000 of the population during the past ten years. In Nigeria, we are ourselves worried by the increasing number of cases of mental breakdown noted among our overseas students, and of cases of endogenous depression and suicide." (Sir Samuel Manuwa, W. Afr. med. J., April, 1963.) 